PAWE $Ł$ NOWAK

ORCID: 0000-0001-8267-1198

Katedra Komunikacji Medialnej

Uniwersytet Marii Curie-Skłodowskiej

\title{
'The sleep of reason brings forth monsters' - the natural order of things and plain language against hatred promotion of totalitarian systems
}

\section{Summary}

The semantic and pragmatic analysis carried out in the article - from the perspective of the natural order and plain language - of slogans used for over a decade during marches and demonstrations of the far-right National Radical Camp in Poland and its sympathisers clearly demonstrates the hateful and propagandist nature of the slogans. This is confirmed by the senders' use of semantic and intentional obscenities, animal- and death-related metaphors, emotionality and aggression of speech acts as well as many other linguistic phenomena inciting hatred.

All this makes it all the more surprising that investigations, proceedings and cases brought before justice institutions and relating to the nationalist and fascist slogans analysed in the article have been repeatedly dismissed or discontinued on the grounds that they do not constitute propaganda and incitement to hatred.

No law can oppose life experience or natural order of things and fail to notice how such utterances are viewed from the perspective of not just the concepts mentioned above, but also of plain language and linguistic logicism.

Keywords: linguistic logicism, simple Polish language, the natural order of things, cognitive heuristics, fascism, slogans.

In 1993 when the National Radical Camp was being registered in Częstochowa, the 1997 constitution of the Republic of Poland had not yet been adopted. Therefore, it was not yet possible to evaluate it from the perspective of article 13 of the Constitution applicable to this day, which reads as follows:

Political parties and other organisations whose programmes are based upon totalitarian methods and the modes of activity of Nazism, Fascism and Communism, as well as those whose pro- 
grammes or activities sanction racial or national hatred, the application of violence for the purpose of obtaining power or to influence State policy, or provide for the secrecy of their own structure or membership, shall be prohibited ${ }^{1}$.

However, Criminal Code provisions were in force which prohibited totalitarian systems and incitement of ethnic, racial or religious hatred and public abuse in this regard $^{2}$.

Therefore from the perspective of the natural order of things, plain language and utility communication it is surprising that an organisation is legalised whose base of activity was a document which reads as follows:

ONR refers to the tradition of the organisation of the same name operating in the times of the $2^{\text {nd }}$ Republic of Poland [...]. A member of ONR realises the danger that comes with foreign elements which endanger the national integrity of the Republic. Always and everywhere stands defending Polish identity, both in case of spiritual and material assets [...]. A member of ONR will pursue the rebirth and care for values in line with the Catholic spirit and Latin culture. (Statut)

On the surface, these statements say nothing wrong, but linguistic communication is not limited to surface only, but the profundity of text is just as important. In this case, firstly there is a reference to the interwar period tradition which was generally respected after 1989 (ref. the celebration of general Piłsudski). However, in the interwar period the ONR was a fascist organisation, ready for war with other nations (especially Jews), which is why it was banned just before the Second World War. Naturally, logically and plainly (though not crudely) referencing this organisation entails identifying oneself as fascist and pugnacious, not democratic and pacifist. This went unnoticed by the court in Częstochowa and many other courts across the country.

There was a second task that demanded immersion into the profundity of the text, and not simply a superficial analysis. The metaphor of foreign elements, loss of national integrity or defending Polish identity, spiritual and material assets on the surface is a beautiful patriotic statement. However, when one translates it with the use of NOT and plain language, a question appears how the defence of national in-

${ }^{1}$ Source: https://www.sejm.gov.pl/prawo/konst/angielski/kon1.htm (accessed: 10.10.2019).

2 Art. 256. "Propagation of fascism or totalitarianism. $\$ 1$. Anyone who publicly promotes a fascist or other totalitarian system of state, or incites hatred based on national, ethnic, race or religious differences or for not being religious, is liable to a fine, the restriction of liberty or imprisonment for up to two years. $\$ 2$. Anyone who distributes, produces, records, or brings, acquires, stores, possesses, presents, carries or sends any print, recording or other object containing the content specified in $₫ 1$, or bearing fascist, communist or other totalitarian symbolismis liable to the same penalty. $₫ 3$. The offender does not commit the offence specified in $\$ 2$, if he is conducting this activity for artistic, educational or scientific reasons, or is a collector. $\$ 4$. In the event of a conviction for the offence specified in $\$ 2$, the court orders the forfeiture of the items referred to in $\$ 2$, even if they are not the property of the offender". The part of this article "bearing fascist, communist or other totalitarian symbolism" lost its force of law in Constitutional Tribunal ruling of 19.07.2011. Art. 257. "Insulting a group or individual. Anyone who publicly insults a population group or an individual because of national, ethnic, race or religious affiliation, or because of not being religious, or for these reasons breaches the personal inviolability of another individual, is liable to imprisonment for up to three years". 
tegrity and Polish identity, spiritual and material assets will be conducted. The metaphor of natural phenomena (elements) used in this statement and an elaborate war metaphor do not leave any doubt that the metaphorical fight, if there is a need, will turn into real war and aggression. ${ }^{3}$ The same meaning can be found in the last of the cited sentences - this time Catholicism will be the only religion for Polish citizens.

At the beginning of the 1990s all such statements, remarks, and texts were disregarded as an expression of liberty - the pluralism and democracy Polish people had longed for decades before. How wrong the courts were while evaluating the danger arising from the activity of such organisations has only come to light over the last few years.

Events of the years 2013-2019 (although many similar cases appeared earlier before) and their escalation in Białystok on the 20th of July 2019 resulted in the need to look into different slogans prepared by the members and proponents of the ONR, with the use of linguistic analysis tools (formal, semantic and pragmatic) and including the category of the natural order of things and plain language. ${ }^{4}$

While analysing any communication and evaluating the activity of institutions and organisations in public space, one can take into account the cognitive heuristics of Levinson (2010) and Szwabe (2008). There are three of them:

1. What is not talked about does not exist.

2. What is plainly described passes stereotypically.

3. What is said in a non-stereotypical way is non-stereotypical.

Each of the organisations which conducts controversial activity and causes unrest and aversion in at least a part of society, refers to these rules, assuming that many things can be concealed by using the first heuristic and convince others of normalcy by using the second heuristic.

The natural order of things and plain language modify these heuristics in order for public communication constructed in line with these rules to become more efficient/useful or correct, clear and economic. Therefore cognitive heuristics modified by linguistic logicism and the role of the client assumed by the users of public texts present as follows:

1. What is not talked about does not exist, because this is completely insignificant or hardly significant for the recipient-client and very well known for the sender, therefore unnecessary for anything else but building one's status and being a 'knowit-all'.

${ }^{3}$ Notion metaphors were introduced this way into texts by propagandists in totalitarian systems (Nowak 2002: 93-124) - war also meant armed combat and building up meant construction of buildings. This balancing on the edge of metaphorical and literal in these texts was extremely effective, persuasive and invisibly causative.

4 Although the material for analysis was gathered in many ways, a lot of evaluated slogans came from documents gathered in the Criminal Expertise Institute 'Analityks' in Poznań, where I am acting as director of the Department of Linguistics and Psychology. 
2. What is plainly described passes stereotypically, because the recipient understands the words used in a text, knows, usually from their own experience, the scenarios evoked in it, as well as notion frames. In this situation, the recipient does not need anything explained because everything is obvious to them.

3. What is said in a non-stereotypical way is non-stereotypical, because phenomena described in this way are exceptionally rare, unusual, specialist, difficult to understand by recipients-clients who are usually unable to correctly interpret them and have never encountered them before.

4. A fourth heuristic could be added here, one that stems from the previous three: Where meaning cannot be explained, there is no sense and/or an illogical explanation also does not make sense.

In the case of the ONR and other totalitarian organisations, the authors of communication reach for all three heuristics, often employing them on the occasion of one match or assembly. At the same time they use common, crude, vulgar and rare celebratory words usually not used by recipients of these texts.

A group of slogans which have appeared over the last ten years during protests, demonstrations and marches organised by the ONR or their proponents consist of 120 texts (in many cases variations of one linguistic template where senders change single words, syntax or other formal aspects of these phrases). For the most part these 'ideological' (consistent with the stature and the new ideological declaration of the ONR) activities and slogans are or were the object of police and prosecutor investigations and court proceedings because the vast majority of them employ simple language, aggressive, stigmatizing, inciting violence towards nations other than Polish (especially Jews and Arabs), towards religions other than Catholicism (especially Islam) and other colours of skin (especially black people). Unfortunately, many of these proceedings, investigations and cases ended in dismissal of the accusations of incitement to hatred and propagating totalitarian systems, because justice institutions rejected the interpretation of these statements in line with the natural order of things and plain language as too obvious, while seeking out and accepting the explanations to the third and fourth heuristic. At the same time, they attributed competences, meanings and intentions to the authors and senders, ones that could not be justified by context nor competence, either semantically or pragmatically. The manners of justifying these phrases were incompliant with the natural order of things and the rules of plain language, therefore completely uncommunicative in the modern public sphere.

Including both these categories, cognitive and linguistic analysis of these statements without leaving out the characterisation of senders, contexts, manners of communication (communication channel) and intended and random recipients, allows for an unambiguous reading of such slogans as infringing the rules of Polish law and makes it necessary to punish their senders. 
In the most obvious way it is visible in slogans which directly incite hatred towards OTHERS ${ }^{5}$. Semantic-pragmatic analysis referring to the natural order of things and plain language indicates at least 31 such slogans, shouts, and chants:

'Fuck you' (shouted for example on the 17th of April 2007 in Cracow during the ONR's 73rd anniversary march) - is a vulgar, aggressive and confrontational English swear word often directed by ONR members' activities, which 'propagate the national idea using different methods', at the opponents of nationalist and fascist movements, foreigners, ethnic groups and believers of religions other than Catholicism, or non-believers. There is no doubt that such words incite hatred, which is included in the ONR ideological programme/declaration in an indirect way, but such actions 'presume or allow racial and national hatred'.

'Wypierdalaj/wypierdalać' ('Fuck off') - same as above, this time in Polish. Hatred, vulgarity and aggression are undeniable.

'Won brudasie' ('Out you dirtbag') - this slogan opens a series of chants, appears on banners and shouts in which, in line with the natural order of things, plain language and semantic-pragmatic analysis, appear contempt, hatred and aggression, an encouragement to attack OTHERS with the use of animalistic metaphors, that is, describing the other person as an animal. It is taking humanity away from the persons discussed, which from the perspective of the natural order of things, plain language and cultural semantics is one of the worst things that can happen to someone. In this case the deprecating interpretation of reality manifests in the word won (out), which is used as a command ordering a dog to go away. In addition, this short vowel sound makes it seem even more aggressive and there is no context (except for a joke, though not a very sophisticated one). Persons whom such words are directed at are treated like dogs, which in Polish phraseology and language is usually not perceived as good. The phrase treat someone like a dog means 'to be aggressive, rude towards someone, to hate someone, talk to someone in the worst possible way'. The word won and the inherent concept of a person as a dog/animal also appear in other slogans, shouts and chants, on banners prepared by members and proponents of the ONR. Among others, these would be the phrase often repeated during different ONR activities: 'Islam won z polskich stron' ('Islam out from Polish land'). In the 'won brudasie' expression the metaphor of useless things/garbage is used (Nemec 1971). The word brudas (dirtbag) literary means 'a dirty person' and dirt is something useless. In a metaphorical sense, brudas means 'black person' and in this context from a colloquial word it becomes derogatory, hatred and aggression-inciting, deeming this person useless (words with a similar meaning include: ścierwo, śmieć, odpad, szmata, łach, smród, gnój).

Another aggressive slogan inciting racial hatred comes from the same Cracow march - 'jebać murzynów' ('fuck niggers'). According to the authors of Stownik

${ }^{5}$ Although in this case rather in the FRIEND-FOE cultural opposition where FOE is evil and has to be fought off by all available means, not just DIFFERENT, as contemporary postmodernism would like it (Łotman 1986; Nowak 2002; Korczyński 2019). 
polszczyzny rzeczywistej (janKomunikant 2011) jebać (fuck) is the second most used (preceded by chuj [dick]) word by Polish people every day which not only expresses emotion or exposes linguistic incompetency of the sender (this role is played above all by the word kurwa [whore]), but also carries a meaning. In this slogan the word means 'hit, strike, inflict strong pain', that is - use violence against others. This is obvious incitement to aggression and racial hatred and it cannot be justified by the fact that this happened after Simon Mol was accused of transmitting HIV/AIDS to several Polish women. Other versions of this slogan were used in the protest against refugees on 12th October 2015 in Gdańsk, and again in the same city on 28th November 2014: 'jebać Islam' ('fuck Islam'), 'Jebać Islam, ale, ale, cała Polska krzyczy razem, muzułmana tylko gazem, jak nie gazem, to na mydło, to jest sposób tępić bydło, a na drzewach zamiast liści będą wisieć islamiści' ('Fuck Islam, the whole of Poland shouts, gas the Muslim, if not gas, make them into soap, this is a way to eradicate cattle, Muslims will be hanging from trees instead of leaves'), 'jebać Arabów' ('Fuck Arabs') and also during the anti-immigration protest on 27th October 2017 in Wrocław: 'Jebać Araba' ('Fuck the Arab').

The slogans 'jebać Islam' and 'jebać Arabów’ suggest on existing permission to incite religious, national and racial hatred and inflict violence. The elaborate linguistic construction from Wrocław is not only encouraging hatred inciting and aggression, but also is an example of the most extreme level of aggression that can be expressed in Polish culture because of the reference to Fascist and Nazi methods of genocide during the Second World War (this is also giving a totalitarian character to the organisation). 'Muzułmana ${ }^{6}$ tylko gazem' isolated could refer to pepper or neutralising gas, as in Polish there are constructions: 'gazem go' ('gas him'), 'potraktować kogoś gazem' ('gas someone'), 'policja użyła gazu do rozpędzenia demonstrantów' ('police used gas on demonstrators'), but the following part 'jak nie gazem, to na mydło' ('if not gas, make them into soap') is an outrageous, hideous and disgusting reference to concentration camps where Fascists and Nazis produced fat for soap from bodies of prisoners who were previously shot or gassed. Another phrase which refers to animalistic metaphors and incites racial and national hatred: 'to jest sposób tępić bydło' ('this is the way to eradicate cattle'). Bydło (cattle) as an animal metaphor is insulting and describes 'aggressive, primitive people', and the word tępić (eradicate) further emphasises the humiliation of persons called this way, as it primarily means 'destruction, thinning', that is - 'murder'. In addition, this word is usually used in reference to rodents (rats, mice). In the case of a lack of this negative enforcement, the syntactically correct words would be wybić or przetrzebić.

${ }^{6}$ Of course the correct form of this word would be muzulmanina, not muzulmana. This also demonstrates that interpreting these slogans and explaining their propagation in another way than the natural order of things and plain language is simply an unnecessary interpretation malpractice and a case of 'killing a bird with a cannon'.

7 The coherent and thematicised reference to fascism and concentration camps, using the rules of the natural order of things, is perhaps used unwittingly, but still should not go unnoticed. After all, the prisoners were transported to the camps in cattle wagons. 
At the same protest in Wrocław the slogan 'Islam won z polskich stron' ('Islam out from Polish land') appeared (a version of it, 'Germans out of Polish land' was used in the ONR's webpage in Brzeg in 2007), which shows the thematisation of ONR messages characteristic for the natural order of things and confirms that the members of this organisation and their proponents not only presuppose and allow racial and national hatred, but explicitly encourage it.

There is also the slogan 'Jebać Unię Europejską' ('Fuck the European Union') which could easily be treated as allowing racial and national hatred towards all the countries and citizens of the EU, for the same reasons mentioned previously regarding slogans with the word jebać.

Another group of slogans with racial and national hatred on the surface of the text, visible from the perspective of the natural order of things and plain language, is precz (begone): 'Żydzi z Polski precz' ('Jews begone from Poland'), 'Nasza święta rzecz, czarni z Polski precz' ('Our sacred thing, blacks begone from Poland'), 'Polska święta rzecz, Żydzi z Polski precz' ('Poland a sacred thing, Jews begone from Poland'), 'Nasza święta rzecz, Żydzi z Polski precz' ('Our sacred thing, Jews begone from Poland'), 'Łapy precz od polskiej ziemi, imigrantów tu nie chcemy' ('Hands off Polish land, we don't want immigrants here'), 'Precz z żydowskim szowinizmem!' ('Begone Jewish chauvinism'), 'Precz z żydowską okupacją' ('Begone Jewish occupation'). They appeared at St. Anne's Mountain in May 2005 and 2006, on the ONR's website in Brzeg in 2007 and at the protest on 11th November 2009 in Warsaw and on 26th October 2015 in Lublin, at a protest against immigrants.

The word precz (begone) in this case means an exclamation ordering someone to go away immediately', therefore it allows and incites racial and national hatred because it forbids Jews, Germans, black people and immigrants to stay in Poland. These slogans are 'Precz z żydowskim szowinizmem!', 'Precz z żydowską okupacją. In Hitler's Germany and territories conquered by the German army, the victims of chauvinism, that is 'extreme nationalism expressed in an uncritical attitude towards one's own nation and in contempt and hate towards other nations', were actually Jews, just as living in German Jewish ghettos was the cruellest of occupations.

In reference to previous analyses and conclusions, nothing is changed in terms of the intention of communication, nor superficial and profound structure, in slogans with the word pierdolic ('to treat someone with disdain, disparagingly'), e.g. 'Ole, ole, ole, Islam pierdolę' ('Ole, ole, ole, fuck Islam', 12th October 2015 in Warsaw), as well as derivatives of this verb e.g. 'Cała Polska śpiewa z nami, wypierdalać z uchodźcami' ('All of Poland sings with us, fuck refugees', march against immigrants, Wrocław, 13th October 2015). In these contexts wypierdalać means 'to throw someone or something out of somewhere' and is a common word, only a little weaker than won and jebać, allowing and inciting racial and national hatred.

Another group of slogans is linguistic constructions placed on banners and chanted during protests or marches organised by the ONR and their proponents, which in their surface construction use a verb in the first person singular with the inclusive 'us', e.g. 'My nie chcemy tu islamu, terrorystów, muzułmanów' ('We don't 
want Islam, terrorists, muslims here'), 'My Chrystusa wyznajemy, demokracji tu nie chcemy' ('We believe in Christ, we don't want democracy here'), 'My Ojczyznę obronimy, imigrantów nie wpuścimy' ('We will protect the Homeland, we won't let immigrants in'). Using the pronoun $m y$ ( $u s$ ) here or an appropriate form of the verb is supposed to include others in activities and ambitions of people who state these slogans, primarily the viewers and listeners at best - all Polish people.

The first and third of these do not seemingly incite racial and national hatred, but in the natural order of things Islam + terrorists + muslims + immigrants, escpecially in the context of the discussion about Poland's accepting of refugees (the first slogan was stated by the ONR at their anniversary march on 29th April 2017 in Warsaw, the second during the protest against immigrants on 26th October 2015 in Lublin), hatred towards these groups and disapproval of their presence in the country.

Even more frightening and aggressive is the slogan: 'My Chrystusa wyznajemy, demokracji tu nie chcemy' ('We believe in Christ, we don't want democracy here') because resigning from democracy means immediate reference to totalitarian methods and practices (demokracji tu nie chcemy, we don't want democracy) and infringes upon all the possible rights of a contemporary person.

The slogan 'Imigrantów tu nie chcemy, repatriantom pomożemy' ('We don't want immigrants, we will help repatriates' from 26th of October 2015 in Lublin) has the same implication, in which the positive 'we will help repatriates' is supposed to conceal aggression towards immigrants - even more so since this slogan was in the vicinity of others, more blunt and obvious: 'Cała Polska śpiewa z nami, wypierdalać z uchodźcami' ('All of Poland sings with us, fuck refugees'), 'Ewa Kopacz chce Murzyna, niech go w domu sobie trzyma' ('If Ewa Kopacz wants a nigger, let her keep him in her home0, 'Polska przeciw imigrantom' ('Poland against immigrants'), 'Repatrianta zamiast imigranta' ('Repatriate in place of immigrant'), 'Wczoraj Moskwa, dziś Bruksela niepodległość nam odbiera' ('Yesterday Moscow, today Brussels takes our independence'), 'Kradzież, gwałty i morderstwa imigrantów to zajęcia' ('Theft, rape and murder are the jobs of immigrants'), 'Nie islamska, nie czerwona, tylko Polska narodowa' ('Not islamic, not red, only national Poland'), 'Każdy Arab niech pamięta, dla nas Polska to rzecz święta' ('Let every Arab remember, Poland is a sacred thing for us'), 'Zachód wojny wywołuje, imigrantów niech przyjmuje' ('The West makes war, let them take the immigrants'), 'Nie islamska, nie laicka, tylko Polska katolicka' ('Not Islamic, not secular, only Catholic Poland'), 'Taki pomysł poprze wariat, by wprowadzić w Polsce szariat' ('Only a loony supports sharia law in Poland'), 'Kresowiakom tak, imigrantom nie' ('Yes to people from Kresy, no to immigrants'), 'Płaczą Niemcy, płacze Francja, tak się kończy tolerancja' ('Germany cries, France cries, that's how tolerance ends'), 'Narodowa Lubelszczyzna. Bóg, Honor i Ojczyzna' ('National Lublin region, God, Honour and Homeland'), 'Opamiętaj się Polaku, Polska tylko dla Polaków' ('Come to your senses, Pole, Poland only for Poles'), 'Łapy precz od polskiej ziemi, imigrantów tu nie chcemy' ('Hands off Polish 
land, we don't want immigrants here'), 'Po zasiłki przyjeżdżają, swoje prawa narzucają? ('Coming for the benefits, imposing their laws), 'Głos narodu za nic macie, imigrantów sprowadzacie' ('You don't care about the nation's voice, you bring in immigrants'), 'Nie lewacka, nie islamska, tylko Polska chrześcijańska' ('Not leftist, not Islamic, only Christian Poland'), 'Cały Lublin głośno krzyczy, nie dla tej islamskiej dziczy' ('All of Lublin shouts loudly, no to these Islamic savages').

In several of these slogans the authors assume the right to speak for all of Poland and at the same time assume and allow national and racial hatred: 'Cała Polska śpiewa z nami, wypierdalać z uchodźcami', 'Polska przeciw imigrantom', 'Nie islamska, nie czerwona, tylko Polska narodowa', 'Każdy Arab niech pamięta, dla nas Polska to rzecz święta,' 'Opamiętaj się Polaku, Polska tylko dla Polaków', 'Nie lewacka, nie islamska, tylko Polska chrześcijańska' or these coming from other protests and marches, very popular among the members and proponents of the ONR 'Polska tylko dla Polaków' ('Poland only for Poles'), 'Cała Polska tylko biała'/'Polska cała tylko biała' ('All of Poland, only white'). Even though these slogans don't always name a nation or race, the natural order of things and plain language clearly indicates that senders encourage recipients to understand the words refugee, immigrant, Islamic as slogans against people of other nations and/or skin colour. The most aggressive among these are those with swear words (wypierdalać) and the last one with the islamska dzicz (Islamic savages) expression. Wypierdalać was mentioned before, as the animalisation and primitivism included in the word $d z i c z$. Shouting those two is definitely not friendly and the intention, both external and internal (Witek 2013) is without a doubt the same - assuming and allowing national and racial hatred even when they don't mention a nation or skin colour.

An important group of slogans are those referencing totalitarian systems (fascist and communist), as well as the history of the ONR and other Polish nationalist, fascist organisations from the interwar period.

In the first group we can find 'Imigranci do obozu' ('Immigrants to camps'), 'Hitler, endek dwa bratanki' ('Hitler, ND-member, two pals'), 'No pasaran krzyczeli komuniści, a my i tak przeszliśmy' ('No pasaran shouted the communists, we crossed anyway!'), 'Zrobimy z wami, co Hitler z Żydami!' ('We will do to you what Hitler did with the Jews'), a song 'Auschwitz Birkenau sia la la la', 'Pray for Islamic Holocaust', 'Załatwimy ich jak Adolf' ('Let's finish them off like Adolf'), 'Fascismo z ziemi włoskiej do Polski' ('Fascismo from Italy to Poland') and headbands with the 'black sun' symbol (shouted and worn on 11th November 2015 in Warsaw, 26th August 2017 in Oświęcim, 9th January 2016 in Bielsko-Biała and 12th September 2015 in Gdańsk). The natural order of things, Poles' life experience and the history of Poland in the 20th century, makes linguistic constructions referencing fascism and the Holocaust in a positive way unimaginably aggressive, mindless, promoting a totalitarian ideology and encouraging the destruction of other nations and races.

The first of these is a modification of a very positive saying "Polak, Węgier dwa bratanki i do bitki, i do szklanki", meaning there are similarities and friendship be- 
tween these two nations (Poland and Hungary). Replacing these nations with Hitler and ND members indicates that ONR members admire the methods and practices of Nazis and fascists, they copy Hitler's methods of treating OTHERS.

The second one refers to the Spanish fascist general Franco and the civil war in Spain in the 1930s. The form przeszliśmy (we crossed) clearly indicated an affinity to fascists and their methods and practices. The last slogan should be interpreted in the same way, as it contains the Italian name fascimo, that is fascism, which is additionally a profanation of Polish national symbols with the use of the national anthem refrain "z ziemi włoskiej do Polski".

However, the most totalitarian and overtly channelling fascism are the slogans referring to the Holocaust. Elements presupposing or allowing racial and national hatred appear. From the natural order of things perspective, these include the singing of a song in Oświęcim, which goes 'Auschwitz Birkenau sia la la la' (with the tune sialalala breaking the rules of social decorum by using a verse characteristic for wedding parties and pop songs) or a prayer for the Holocaust ('Pray for the Islamic Holocaust'). Among these slogans there are also directives with threats to destroy OTHERS by means of fascism ('Zrobimy z wami, co Hitler z Żydami!', 'Załatwimy ich jak Adolf').

Slogans which reference other totalitarian systems and ideologies presupposing hatred for other nations and races are as follows: 'Narodowy radykalizm uderz, uderz w kapitalizm' ('National radicalism hit capitalism'), 'Czołem Wielkiej Polsce' ('Hail to Great Poland'), 'Biała siła, czarna kiła' ('White power, black lues'), 'Raz sierpem, raz młotem czerwoną hołotę ('Hit red vermin with hammer and sickle'), 'Raz sierpem raz młotem czerwoną hołotę, good night lefties', 'Znajdzie się kij, na żydowski ryj' ('We will find a stick for Jewish gobs'), 'Śmierć wrogom ojczyzny' ('Enemies of homeland die'), 'A na drzewach zamiast liści będą wisieć komuniści' ('And from the trees instead of leaves communists will hang'), 'Każdy inny, wszyscy biali' ('Each different, everyone white'), 'Znajdzie się kij na lewacki ryj' ('We will find a stick for leftist gobs'), 'Znajdzie się kij na pedalski ryj' ('We will find a stick for queers' gobs'),'KOD, Nowoczesna, GW, Lis, Olejnik i inne ladacznice - dla was nie będzie gwizdów, będą szubienice' ('KOD, Nowoczesna, GW, Lis, Olejnik and other whores - for you not whistles but gallows'), 'A na drzewach zamiast liści będą wisieć syjoniści' ('And from the trees instead of leaves Zionists will hang'), 'Biała Europa braterskich narodów' ('A White Europe of brotherly nations'), 'A na drzewach zamiast liści będą wisieć islamiści' ('And from the trees instead of leaves Muslims will hang'), 'ONR Pruszków, Życie i śmierć dla narodu' ('ONR Pruszków life and death for the nation'), 'Europa dla białych, Afryka dla HIV' ('Europe for whites, Africa for HIV'), 'Biała Siła' ('White power'), 'Europa będzie biała albo bezludna' ('Europe will be white or uninhabited'), 'Stolica Polaków nie chce lewaków' ('The Polish capital doesn't want leftists'), 'Czysta krew, trzeźwy umysł, Europa będzie biała albo bezludna' ('Pure blood, clear mind, Europe will be white or uninhabited'), 'Nie islamska, nie czerwona, tylko Polska narodowa' ('Not islamic, not red, only national Poland'), 'Nie lewacka, nie islamska, tylko Polska chrześcijańska' 
('Not leftist, not islamic, only Christian Poland'), 'Narodowy socjalizm' ('National socialism'), 'Wielka Polska katolicka' ('Great Catholic Poland').

The most common in this group are repetitive phrases: A na drzewach zamiast liści będa wisieć komuniści/ syjoniści/ islamiści and Znajdzie się kij na żydowski/ lewacki/ pedalski ryj. In a superficial structure these are statements/assertions, but said in the context of protests and marches by the ONR or their proponents yet in line with the natural order of things these are directives, that is, communication making the world as it is. This is nothing short of threats directed at the indicated persons or social groups, as well as statements allowing national and political hatred, also towards sexual orientation or outright calling out its consequences.

In this set there are several statements which appear in the above-mentioned protests and marches and to some degree echo the programme and slogans of the Ku Klux Klan: 'Biała siła, czarna kiła' and 'Europa dla białych, Afryka dla HIV' (these appeared in relation to Simon Mol's story), 'Każdy inny, wszyscy biali', 'Biała Europa braterskich narodów,' 'biała siła, 'Europa będzie biała albo bezludna,' 'Czysta krew, trzeźwy umysł, Europa będzie białą albo bezludną. Here, just as in previous slogans, all of them are locutionarily assertions, but illocutionarily directives and commissives assuming national and racial hatred. In many of them the adjective 'white' appears as a way to describe the colour of skin, but it is also an indirect message at ONR protests against the presence in Poland or Europe of people of different nationalities or skin colour.

There are also hidden quotes and references to Polish nationalist and fascist organisations from the interwar period, which confirms the insincerity and secrecy of the new ideological declaration where the ties to Obóz Wielkiej Polski were to remain hidden.

An obvious quotation from a name of an organisation is 'ONR Pruszków. Życie i śmierć dla narodu' as one of the Ruch Narodowo-Radykalny Falanga's most radical and aggressive divisions was called the NOB (Narodowa Organizacja Bojowa) 'Życie i Śmierć dla Narodu'.

Equally obvious are the references in slogans 'Czołem Wielkiej Polsce,' 'Wielka Polska katolicka', as they contain parts of the name of a fascist organisation Obóz Wielkiej Polski and/or are the mottos of nationalist and fascist organisations from the 1930s.

At first glance the slogan 'Śmierć wrogom ojczyzny' seems quite harmless, as in the natural order of things and plain language, the enemies of the homeland should die. However, currently Poland is not at war with anyone, which could evoke the suspicion that the enemy here might be another nation or people of different skin colour. Apart from that, this slogan - in the form of S.W.O. - along with a skull and crossbones was worn by 'Bury' and his soldiers who disgraced themselves after the Second World War when they pacified Belarussian and Ukrainian villages in the Białostocczyzna region. A slogan referring to a nationalist murderer cannot be in line with article 13 of the Polish constitution and not infringe Polish rule of law. 
Nationalism, close to fascism when it comes to certain totalitarian characteristics and assuming national and racial hate, is present in the following slogans: 'Raz sierpem, raz młotem czerwoną hołotę, 'Raz sierpem raz młotem czerwoną hołotę, good night lefties', 'KOD, Nowoczesna, GW, Lis, Olejnik i inne ladacznice - dla was nie będzie gwizdów, będą szubienice', 'Stolica Polaków nie chce lewaków', 'Nie islamska, nie czerwona, tylko Polska narodowa', 'Nie lewacka, nie islamska, tylko Polska chrześcijańska, 'Narodowy socjalizm'. Each of these slogans intends to restrict the freedom of speech, allow hatred towards ideas different than nationalistic ones and there are death threats towards specific organisations, media and persons.

In the material gathered in the years 2007-2019 there are several more slogans of different themes and forms, e.g. 'Tu jest Polska nie Izrael' ('here it's Poland, not Israel'), 'Nasze kamienice, nasze ulice' ('Our buildings, our streets'), 'Polskie kozy obronimy, islamistów nie wpuścimy' ('We will defend Polish goats, we will keep Islamists away'), 'Stop multiculti', 'Stop imigracji' ('Stop immigration'), 'Dziś imigranci, jutro terroryści' ('Today immigrants, tomorrow terrorists'), 'Polska nie dla islamu' ('Poland not for Islam'), 'Polacy przeciw imigrantom' ('Polish against immigrants'), 'Sodomia szkodzi zdrowiu' ('Sodomy damages your health'), 'Stop islamizacji Europy' ('Stop the islamisation of Europe'), 'Wczoraj Moskwa, dziś Bruksela niepodległość nam odbiera' ('Yesterday Moscow, today Brussels takes our independence'), 'Kradzież, gwałty i morderstwa imigrantów to zajęcia' ('Theft, rape and murder are the jobs of immigrants'), 'Zachód wojny wywołuje, imigrantów niech przyjmuje' ('The West makes war, let them take the immigrants'), 'Po zasiłki przyjeżdżają, swoje prawa narzucają' ('Coming for the benefits, imposing their laws), 'Głos narodu za nic macie, imigrantów sprowadzacie' ('You don't care about the nation's voice, you bring in immigrants'), 'Islamiści to pedofile' ('Islamists are paedophiles'). From the perspective of the natural order of things and plain language, in each of these the language of the ONR and their proponents is full of aggression, hatred and references to the totalitarian methods and practices of fascism and Nazism.

$$
\because * *
$$

Many of these 100 slogans evidently infringe social norms, rules of Polish law and article 13 of the Polish Constitution, especially in the case of vulgarisms and directives to leave Poland directed at persons of different skin colour, nationality, religion or sexual orientation. However, there is quite a large collection of slogans which conceal their basic purpose as well as the aim of most ONR's activities.

In order to hide their true purpose, ONR members try to exclude the natural order of things present in common language and available to nearly all language users, through structural interventions concerning the context and means of communication, as well as strictly linguistic tricks, avoiding the use of plain language which, just as the natural order of things, is comprehensible for most Polish people. 
In the communication part this is an attempt to dilute responsibility for these slogans among the participants of the ONR's activities with different positions within the organisation, being only 'proponents' or not being affiliated at all. Similarly, the ONR solves the matter of responsibility for marches, protests and assemblies and often the persons responsible are not ONR members.

The natural order of things, that is, the typical script/scenario of this activity clearly indicated that organisers are responsible for slogans and shouts stated at an event, as is the ONR, whose declaration without a doubt identifies with these slogans.

On the linguistic level, however, especially semantic and pragmatic, when avoiding plain language the senders of these slogans use intermediate speech acts, suggesting a form of expression different than in line with the NOT. Underneath the locution of assertion, that is, only informative speech acts, the ONR senders and their affiliates attempt, in the illocution of these statements, to convey a directive or commissive intention to the recipient and, as a result, propagate fascism, the use of totalitarian methods and Nazi practices whose programme and activity assume or allows racial and national hate. Therefore, it is not surprising that the result of these actions, the perlocution of this communication, are reports of crimes and offences to police stations or prosecutors, because the natural order of things clearly indicated the purpose of the ONR's activity.

In this analysis and interpretation of nationalist and fascist slogans based on the natural order of things and plain language, very few things may cause any doubt. Therefore, it is surprising how many legal institutions have difficulties in finding incompatibilities of these activities with Polish law. Pondering on semantic nuances and considering shades of meanings when slogans analysed in this text are shouted out by crowds marching through city centres and demonstrators throw firecrackers and stones, being aggressive with people who do not agree with them or participate in their activities, destroying other people's belongings, is completely unnecessary if we take into account the perspective of the natural order of things and plain language ${ }^{8}$.

${ }^{8}$ In this case it is difficult to agree with the ruling of the Supreme Court from 1st September 2011 signature act V KK 98/11 (OSNwSK nr 1/2011, position 154): "the activity of 'inciting hate' is connected with the desire to evoke negative emotions (similar to 'hostility') towards a specific nationality, ethnic group or race. It is not in any case prompting the feelings of disapproval, antipathy, prejudice, aversion. Sharing this opinion, the Supreme Court additionally recognised the need to bring attention to the lack of real risks of introducing a totalitarian dictatorship and to two rules of guarantee character which should be taken into account while reading the meaning of criminal law if the interpretation was to lead to the broadening of criminal sanctions of the accused (due to the rule nullum crimen, nulla poena sine lege); secondly - legal expressions should not be given meaning other than colloquial unless there are substantive agreements to do so". 


\section{References}

janKomunikant: Bednorz M., Fąka P., Fleischer M., Grech M., Jankowska K., Siemes A., Wszołek M. (2011): Słownik polszczyzny rzeczywistej, Łódź.

Korczyński T.M. (ed.) (2019): Swój - Obcy - Wróg. Wędrówki w labiryntach kultur, Gdańsk. Levinson S.C. (2010): Pragmatics, Cambridge.

Łotman J. (1986): Problemy komparatystyki semiotycznej, [in:] Problemy wiedzy o kulturze, A. Brodzka, M. Hopfinger, J. Lalewicz (eds.), Wrocław, pp. 5-17.

Nemec I. (1971): Neplnohodnotnost jako zdrojexpresivitgy, [in:] Miscellanea linguistica, F. Kopecny, M. Komarek (eds.), Ostrava, pp. 63-69.

Nowak P. (2002): SWOI i OBCY w językowym obrazie świata, Lublin.

Statut: http://magnapolonia.wroc.pl/dokumenty-archiwalne/archiwalny-statut/ (accessed: 5.08.2019). Szwabe J. (2008): Odbiór komunikatu jako zadanie poznawcze. Ujęcie pragmatyczno-kognitywne, Poznań. Witek M. (2013): Spór między internalizmem i eksternalizmem w teorii aktów mowy, [in:] Metodologie językoznawstwa V. Ewolucja języka, ewolucja językoznawstwa, P. Stalmaszczyk (ed.), Łódź, pp. 161-177.

\section{"Gdy rozum śpi, budzą się demony" - naturalny porządek rzeczy i prosty język przeciw nienawiści i propagowaniu ustrojów totalitarnych}

Abstrakt:

Przeprowadzona w tekście analiza semantyczna i pragmatyczna haseł wykorzystywanych w ostatnich kilkunastu latach podczas marszów i manifestacji ONR-owców i ich sympatyków z perspektywy naturalnego porządku rzeczy i prostego języka nie pozostawia żadnych wątpliwości co do ich nienawistnego i propagandowego charakteru.

Oczywiście, ten fakt potwierdzają używane przez nadawców semantycznie i intencjonalnie sprawcze wulgaryzmy, metaforyka zwierzęca i metafory śmieci, emocjonalność i agresja aktów mowy oraz wiele innych zjawisk językowych, które nakręcają spiralę nienawiści.

Tym bardziej dziwi wielokrotne oddalanie lub przerywanie dochodzeń, postępowań i spraw prowadzonych przez instytucje wymiaru sprawiedliwości, a związanych $\mathrm{z}$ analizowanymi $\mathrm{w}$ tym tekście hasłami nacjonalistycznymi i faszystowskimi ze względu na brak znamion propagowania i nawoływania do nienawiści.

Żadne prawo nie może być niezgodne z doświadczeniem życiowym czy naturalnym porządkiem rzeczy i nie dostrzegać, co o tego typu wypowiedziach poza wymienionymi już koncepcjami sądzą także prosty język i logicyzm językowy.

Słowa kluczowe: logicyzm językowy, prosty język polski, naturalny porządek rzeczy, heurystyki poznawcze, faszyzm, slogany. 